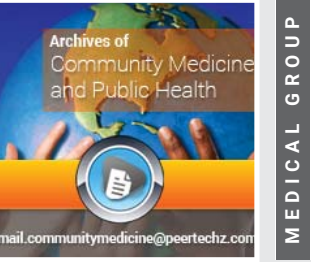

\title{
A survey of hand hygiene knowledge, attitude and practices among health care workers in a tertiary hospital, Southwestern Nigeria
}

\author{
RD Agbana ${ }^{1}$, SP Ogundeji ${ }^{2}$ and JS Owoseni ${ }^{3 *}$ \\ 'Department of Community Medicine and Public Health, College of Medicine and Health Sciences, Afe \\ Babalola University, Ado Ekiti, Nigeria \\ ${ }^{2}$ Department of Haematology, College of Medicine and Health Sciences, Afe Babalola University, Ado \\ Ekiti, Nigeria \\ ${ }^{3}$ Department of Sociology, Ekiti State University, Ado-Ekiti, Nigeria
}

Received: 15 May, 2020

Accepted: 25 July, 2020

Published: 27 July, 2020

*Corresponding author: Dr. JS Owoseni, Department of Sociology, Ekiti State University, Ado-Ekiti, Nigeria, E-mail: sina.owoseni@eksu.edu.ng

Keywords: knowledge; Attitude; Prevalence; Hand hygiene healthcare workers

https://www.peertechz.com

Check for updates

\section{Abstract \\ Background: Improper hand hygiene practices among Healthcare Providers (HCPs) are a common risk factor for and interventions to improve hygiene have proven to be effective strategy in reducing nosocomial infection. Hand hygiene has been described as the single most important, simplest and least expensive means of preventing} nosocomial infections.

Aim/Objectives: The studied was carried out to determine the knowledge, attitude and practice of hand hygiene among healthcare workers in a tertiary health facility.

Materials/Methods: A cross- sectional study was conducted among 368 doctors, nurses and ward attendants using multistage sampling technique. Data were collected with a set of self- administered, modified WHO questionnaire and analyzed using IBM and SPSS version 25 statistical package.

Results: The mean age of respondents was $35.2 \pm 9.3$ years, and majority of them were between $36-45 y e a r s$ (33.6\%). The male to female ratio was $1.6: 1$. Most of the respondents were nurses (41.5\%) and 370 (98.95\%) of the respondents had a good knowledge of hand hygiene. Washing of hands before and after contact with patients was $44.65 \%$ and $56.2 \%$ respectively. Most of them have received training on hand washing in the last three years (53.4\%), 222 (62.7\%) respondents routinely used alcohol based hand rub. The main reason cited for not observing hand hygiene practices consistently were lack of running water (53.4\%), unavailability of alcohol based hand $\operatorname{rub}(26.6 \%)$, and dirty water sinks (24.0\%).

Conclusion: Although knowledge, attitude and practice of hand hygiene were good among respondents in this study, lack of running water and unavailability of alcohol based hand rub remain major constraints. Hospital management should therefore provide adequate water supply and materials for sanitation and hand hygiene in healthcare facilities.

\section{Introduction}

Hand hygiene has been identified as e an effective means of infection prevention and control in the hospital and even outside of the hospital environment as exemplified by the preventive strategies employed to tackle the corona virus
(Covid-19) pandemic ravaging the world [1,2]. Healthcare workers have been identified as the most common vehicle for transmission of Hospital Acquired Infection (HAI) from patient to patient and within the healthcare environment $[3,4]$. Since Australian- Hungarian physician Ignaz Semmelweis discovered the importance of hand wash in 1858 , good hand hygiene is 
considered to reduce infection transmissibility in the hospital setting [5,6]. Although hand hygiene can be described as an effective, simple, cheap and not time consuming HAI control strategy most studies show low compliance rate of between $40 \%$ and $70 \%[7,8]$. HCW have reported several factors that negatively impact their adherence with recommended practices including but not limited to; inadequate knowledge and lack of awareness, hand washing agents cause irritation and dryness, sinks are inconveniently located, lack of soap and paper towels, not enough time, over workload with understaffing, lack of knowledge of guidelines/protocols, and forgetfulness [9-12].

According to WHO an estimate1.4 million patients acquire HAI at any time and improper hand hygiene accounts for about $40 \%$ of this incidence [13]. The prevalence of HAI varies from one region of the world to another. It affects $5-15 \%$ of hospitalized patients in developed country with higher figures quoted for developing countries [14,15]. Diarrhoea diseases and respiratory tract infections are among the leading contributors to the global burden of disease and poor water supply related to hand hygiene represents $7 \%$ of the risk factors [7].

The fact that hand hygiene significantly reduces nosocomial infection is important in our environment where health facilities are ill-equipped to provide comprehensive support in terms of molecular diagnosis of infectious diseases and high antibiotic resistance due to widespread over the counter procurement [16].

The study was conducted to assess the knowledge, attitude and practice of hand washing among HCW at the Federal Teaching Hospital Ido Ekiti which is a tertiary health centre in Southwester Nigeria. The study further aimed to identify factors hampering the practice of hand washing among the respondents. The finding of this study would help the management as well as the infection control unit of the hospital to institutionalized appropriate measures to increase the compliance rate of hang hygiene thereby with the ultimate aim of reducing the prevalence of HAI.

\section{Materials and methods}

\section{Setting}

The study was conducted at the Federal Teaching Hospital, Ido -Ekiti (FETHI), located in Southwestern Nigeria. The hospital was established in 1954 as a general hospital, upgraded to a Federal medical centre in 1988 and became a teaching hospital in 2014. It serves as a referral centre for all other health institutions in Ekiti and neighbouring states. The hospital comprises of 300 bed spaces including Intensive Care Unit (ICU).

\section{Study population}

This consists of 260 doctors, 400 nurses and 500 ward attendants as at when the study was carried out. All the doctors, nurses and ward attendants working in the hospital at the time of study and willing to participate were included in the sampling $g$ frame. HCW who declined consent and those with injuries, bandages or any other barrier to hand washing were excluded.

\section{Study design}

This was questionnaire based cross sectional descriptive study. A multistage sampling g technique was used to select participants.

\section{First stage}

Six departments (Paediatric, Obstetric and Gynaecology, Community Medicine, Family Medicine, Psychiatry and Internal Medicine) were randomly selected from 11 clinical departments of the hospital using table of random numbers.

\section{Second stage}

At the departmental level, HCW in each department were stratified in to doctors, nurses and ward attendants. Questionnaire allocated to each department were subsequently allocated to each stratum.

\section{Third stage}

The list of HCW in each stratum was obtained via the departmental Heads and the questionnaire was then administered to participants using systematic random sampling after determining the sampling fraction.

\section{Sample size determination}

Sample size was determined using the Fishers formula to obtain a total of 368 based on $95 \%$ confidence interval and $5 \%$ c margin of error. The sampling was limited to doctors, nurses and ward attendants whose hand hygiene practices can either minimize or perpetuate the transmission of infections.

\section{Data collection}

Data collection was done using a pretested, structured and self-administered questionnaire. The questionnaire consisted of 4 sections: with section A) exploring the socio-demographic characteristics, B) consisting of questions on the level knowledge and attitude of hand washing, C) consists of the prevalence and practice of hand washing and D) limitations and solutions to problems of hand washing practices. The investigators personally delivered the questionnaires to the participants after a detailed explanation of the study was provided. Written consent was obtained from those who consented and confidentiality was ensured throughout the study.

\section{Data analysis}

Data was analysed using IBM and SPSS (statistical package for the social sciences) statistical version 25 using inferential statistics. The data was presented in percentages and frequency table. Results were interpreted and conclusions were drawn.

\section{Ethical}

Ethical approval was obtained from the Ethics and Research committee of the hospital. 


\section{Results}

A total of 368 questionnaires were administered and 354 were appropriately completed and analyzed. The response rate was $96.2 \%$, out of which 126 (35.6\%), 147(41.5\%) and 81 $(22.9 \%)$ were doctors, nurses and ward attendants respectively. There were $134(37.9 \%)$ males and 220 (62.1\%) females respectively. Their ages ranged from 17-59 years with a mean of $35.5 \pm 9.3$ years. The HCW were fairly uniformly distributed across the 6 departments with the highest proportion (20.1\%) from Internal Medicine (Tables 1-3).

All the respondents are aware of hand hygiene practices and a large proportion (72.3\%) was informed by HCW while in training. Only $53.4 \%$ of the participants had ever received any form training on hand washing in the use preceding 3 years however $62.7 \%$ routinely alcohol -based hand rub for hand hygiene. Less than half $(45.5 \%)$ of the HCW under study knew the estimates of hospitalized patients who may develop HAI and only $47.5 \%$ of them knew that hand hygiene was very highly effective in preventing HAI.

Eighty -two percent knew that hand washing could prevent respiratory tract infections $96 \%$ diarrhoea diseases. Only about $29.7 \%$ of them responded in the affirmative that hand washing was given a high priority in the studied institution, $42.7 \%$ said they did not know the average percentage of situations that they actually performed hand rubbing and about two fifth $(40.4 \%)$ declared that at least one minute is needed for alcohol-based hand-rub to kill germs

Majority of the respondents chose hand washing over rubbing as a better hygiene method before palpation of patients $(61.6 \%)$,giving an injection $(75.5 \%)$, after emptying a bedpan $(92.7 \%)$, after removing examination gloves $(82.2 \%)$,

Table 1: Socio- demographic characteristics of the respondents.

\begin{tabular}{|c|c|c|}
\hline Variable & $\begin{array}{c}\text { Frequency } \\
n=354\end{array}$ & $\begin{array}{c}\text { Percentage } \\
(\%)\end{array}$ \\
\hline \multicolumn{3}{|l|}{ Age (years) } \\
\hline $15-25$ & 67 & 18.9 \\
\hline $26-35$ & 115 & 32.5 \\
\hline $36-45$ & 119 & 33.6 \\
\hline$\geq 46$ & 53 & 15 \\
\hline \multicolumn{3}{|l|}{ Gender } \\
\hline Male & 134 & 37.9 \\
\hline Female & 220 & 62.1 \\
\hline \multicolumn{3}{|l|}{ Level of education } \\
\hline \multicolumn{3}{|l|}{ School certificate } \\
\hline \multicolumn{3}{|l|}{ Undergraduate } \\
\hline Graduate & 224 & 63.3 \\
\hline \\
\hline \multicolumn{3}{|l|}{ Ward attendant } \\
\hline \multicolumn{3}{|l|}{ Nurse } \\
\hline \multicolumn{3}{|l|}{ Doctor } \\
\hline \multirow{6}{*}{$\begin{array}{c}\text { Department } \\
\text { Internal medicine } \\
\text { Psychiatry } \\
\text { Community medicine } \\
\text { Family medicine } \\
\text { Obstetrics and Gynaecology } \\
\text { Paediatrics }\end{array}$} & 71 & 20.1 \\
\hline & 45 & 12.7 \\
\hline & 55 & 15.5 \\
\hline & 50 & 14.1 \\
\hline & 66 & 18.6 \\
\hline & 67 & 18.9 \\
\hline
\end{tabular}

Table 2: knowledge and attitude of hand washing among respondents.

\begin{tabular}{|c|c|c|}
\hline Variable & $\begin{array}{c}\text { Frequency } \\
n=354\end{array}$ & $\begin{array}{l}\text { Percentage } \\
(\%)\end{array}$ \\
\hline $\begin{array}{l}\text { Ever heard about hand washing practices } \\
\text { Yes }\end{array}$ & 354 & 100.0 \\
\hline $\begin{array}{l}\text { Sources of information } \\
\text { Media } \\
\text { Health workers } \\
\text { Lectures } \\
\text { Friends/ Relatives }\end{array}$ & $\begin{array}{l}129 \\
256 \\
186 \\
91\end{array}$ & $\begin{array}{l}36.4 \\
72.3 \\
52.5 \\
25.7\end{array}$ \\
\hline $\begin{array}{l}\text { Ever received training in hang hygiene in the last } \\
\qquad \begin{array}{c}3 \text { years } \\
\text { Yes } \\
\text { No }\end{array}\end{array}$ & $\begin{array}{l}189 \\
165\end{array}$ & $\begin{array}{l}53.4 \\
46.6\end{array}$ \\
\hline $\begin{array}{l}\text { Routinely use alcohol- based hand -rub for hand } \\
\text { hygiene } \\
\text { Yes } \\
\text { No }\end{array}$ & $\begin{array}{l}222 \\
132\end{array}$ & $\begin{array}{l}62.7 \\
37.3\end{array}$ \\
\hline $\begin{array}{l}\text { Percentage of patents who develop a HAI } \\
\qquad \begin{array}{c}\leq 10 \% \\
11-30 \\
31-50 \\
>51 \\
\text { Don't know }\end{array}\end{array}$ & $\begin{array}{c}62 \\
72 \\
23 \\
4 \\
193\end{array}$ & $\begin{array}{c}17.5 \\
20.3 \\
6.5 \\
1.1 \\
54.5\end{array}$ \\
\hline $\begin{array}{l}\text { Effectiveness of hand hygiene in preventing } \\
\qquad \begin{array}{c}\text { Very low } \\
\text { Low } \\
\text { High } \\
\text { Very high }\end{array}\end{array}$ & $\begin{array}{c}6 \\
18 \\
162 \\
168\end{array}$ & $\begin{array}{c}1.7 \\
5.1 \\
45.8 \\
47.5\end{array}$ \\
\hline $\begin{array}{l}\text { What hand can prevent * } \\
\text { Malarial } \\
\text { Diarrhoea diseases } \\
\text { Pneumonia } \\
\text { Respiratory tract infection }\end{array}$ & $\begin{array}{c}91 \\
340 \\
242 \\
290\end{array}$ & $\begin{array}{l}25.7 \\
96.0 \\
68.4 \\
81.9\end{array}$ \\
\hline $\begin{array}{l}\text { How important is hand washing to your } \\
\text { institution } \\
\text { Low priority } \\
\text { Moderate priority } \\
\text { High priority } \\
\text { Very high priority }\end{array}$ & $\begin{array}{c}66 \\
20 \\
163 \\
105\end{array}$ & $\begin{array}{c}18.6 \\
5.6 \\
46.0 \\
29.7\end{array}$ \\
\hline
\end{tabular}

after making patient bed (77.4\%) and after visible exposure to blood $(92.7 \%)$

About 57.6\% washed their hands over 5 times during their shift and $44.6 \%$ practiced hand-washing occasionally before interacting with patients while $56.2 \%$ said they practiced it always after having patient interactions. Lack of water was the most identified reason $(53.45 \%)$ limiting hand washing practice. In fact, about $60 \%$ of the HCW said water and soap were only readily available for hand -washing in their department's occasionally. However, $76.6 \%$, $78.5 \%$, and $57.3 \%$ of the respondents asserted that their heads of departments, colleagues and patients respectively attached a very high importance to optimal hand hygiene. Also, about $72.3 \%$ thought that they always require substantial efforts to perform good hand hygiene.

Finally on how to improve hand-washing amongst HCWs at the studied centre, $68.1 \%, 52,8 \%, 34.7 \%$, and $14.4 \%$ suggested provision of adequate alcohol-based sanitizers, provision of adequate soap and water supply, lectures and seminars on hand washing and formulation of firm hand-washing policies respectively.

Citation: Agbana RD, Ogundeji SP, Owoseni JS (2020) A survey of hand hygiene knowledge, attitude and practices among health care workers in a tertiary hospital, Southwestern Nigeria. Arch Community Med Public Health 6(2): 146-151. DOI: https://dx.doi.org/10.17352/2455-5479.000095 
Table 3: Practices of hand washing among respondents.

\begin{tabular}{|c|c|c|}
\hline Variable & $\begin{array}{c}\begin{array}{c}\text { Frequency } \\
n=354\end{array}\end{array}$ & $\begin{array}{c}\text { Percentage } \\
(\%)\end{array}$ \\
\hline $\begin{array}{l}\text { Average percentage of situations you actually } \\
\text { perform hand washing } \\
\qquad \begin{array}{c}\leq 20 \% \\
21-40 \% \\
41-60 \% \\
61-80 \% \\
81-100 \% \\
\text { Don't know }\end{array}\end{array}$ & $\begin{array}{c}7 \\
15 \\
23 \\
53 \\
105 \\
151\end{array}$ & $\begin{array}{c}2.0 \\
4.2 \\
6.5 \\
15.0 \\
29.7 \\
42.7\end{array}$ \\
\hline $\begin{array}{l}\text { Number of times you wash hands } \\
\qquad \begin{array}{c}\text { 1-2times } \\
\text { 3-5times } \\
\text { Over } 5 \text { times }\end{array}\end{array}$ & $\begin{array}{c}55 \\
95 \\
204\end{array}$ & $\begin{array}{l}15.5 \\
26.8 \\
57.6\end{array}$ \\
\hline $\begin{array}{l}\text { How often do you practice hand-washing before } \\
\text { interacting with patients } \\
\qquad \begin{array}{c}\text { Never } \\
\text { Always } \\
\text { Occasionally } \\
\text { No response }\end{array}\end{array}$ & $\begin{array}{c}44 \\
133 \\
158 \\
5\end{array}$ & $\begin{array}{c}12.4 \\
37.6 \\
44.6 \\
1.4\end{array}$ \\
\hline $\begin{array}{l}\text { How often do you practice hand-washing after } \\
\text { interacting with patients } \\
\text { Never } \\
\text { Always } \\
\text { Occasionally } \\
\text { No response }\end{array}$ & $\begin{array}{c}20 \\
199 \\
128 \\
7\end{array}$ & $\begin{array}{c}5.6 \\
56.2 \\
36.2 \\
2.0\end{array}$ \\
\hline
\end{tabular}

\section{Discussion}

This study assessed the knowledge, attitude and practice of hand washing among HCW in a tertiary hospital setting unlike most previous studies which were community based.

HAIs are an important causes of morbidity and mortality in clinical practice and pose ethical challenge to healthcare delivery ("nonmaleficence -first, don no harm") [17]. One of the easily identified routes of transmission of HAI is the hands of HCW $[18,19]$. HAI are a burden to both physicians and patients, as they lead to complications in therapy, overall increase in admission days, increase healthcare costs and may result in mortality $[4,20]$.

All respondents interviewed were aware of hand washing practices. About $99 \%$ of the respondents in this study demonstrated good knowledge and attitude to hand- washing practices which are in agreement with other studies in Sokoto, also in Lagos University Teaching Hospital Nigeria and a tertiary healthcare in India that reported $91.7 \%, 83 \%$ and $74 \%$ respectively $[1,8,21]$. The good knowledge of hand hygiene among most of the respondents in this study and others conducted in different populations across Nigeria is likely due to their training in school and the public campaign on hand hygiene in the country as result of recent Ebola virus disease and perennial Lassa fever infection.

Also, the findings from this study show that the rates of compliance in our hospital are still very low as only $29.7 \%$ of the HCW could claim to have actually performed handwashing on an average of 81 to $100 \%$ of situations and an alarming $42.7 \%$ of them could not even remember. Similarly, only about $56.2 \%$ practiced hand-washing after interacting with patients and $5.6 \%$ said they never did. The reasons for this could include lack of continuous educational programme on hand hygiene; unfortunately, HCW in developing countries such as ours consider such programme as mundane. A similar study shows that despite the various advancement in infection control, HCW still do not fully adhere to the recommended hand hygiene practices and as such compliances was still low [5]. In a systematic review by Erasmus, et al. [22], on hand hygiene practices, it was discovered that in ICUs and general wards, the compliance rate was $40 \%$ among physicians. This goes to show that even in critical care units in hospitals compliance with hand hygiene is still a topical issue.

The limiting factors in the practices of hand-washing before and after patients contact mentioned by the respondents like lack of water, unavailability of alcohol-based hand-rub, dirty water sinks, forgetfulness among others were in congruous with reports from an earlier study [21]. Hand hygiene has therefore been promoted as one of the tools that will help to mitigate rise in antimicrobial resistance [23].

In this present study, we observed that several personnel did not perform hand hygiene before conducting an invasive procedure but simply went on to don their gloves. This finding buttress the fact that for them hand hygiene was basically for their own protection and not that of the patient or immediate environment.

The behavioural pattern is also seen on our study with low levels of compliance with the WHO five moments of hand hygiene [24,25]. A worrisome trend is the high noncompliance rates of hand hygiene after touching patients at hands of HCW could then become reservoir for the transmission of pathogens among patients. The several infection causing microorganisms are regularly mutating and as such antimicrobial resistance rates are higher in HAI compared to the community $[14,26,27]$. Such pathogens may therefore enter into the local community via 3 means : HCW, discharged patients who become asymptomatic carrier or the relatives who had visited the hospital.

At the moment, the situation in developing countries is such that hand-washing facilities are suboptimal [28]. Non availability of sufficient sinks and running water are also recognized impediment. In addressing hand hygiene, however, alcohol-based hand rubs are become handy. Furthermore, educational programmes must also be supplemented with the presence of an effective infection control team. There must also be active surveillance system in place to rapidly detect cases of HAI and nip further ones in the bud [29-31]. Such surveillance system may also use personnel who have high rates of patient contact to drive the process.

The highest rates of direct patient contact in this study were in the nurses and the anaesthetists. These two categories of HCW are points of easy access to both patients and other heathcare personnel and as such interventional measures may be designed around them.

The WHO has recommended guidelines $[2,30]$, for hand hygiene and its central theme is to wash hands with soap and water when it is visibly dirty or soiled with blood or other body 
fluids or after toilet use. The guidelines recommend washing with water and soap or an alcohol-based hand rub. Studies on efficacy of alcohol-based hand rub show that they have good efficacy when the concentration of alcohol ranges from $62 \%$ to $95 \%$ thus ensuring that they are rapidly bactericidal [32].

Promoting the use of alcohol-based hand rubs in hospital in developing countries such as ours may help drive down the rates of HAI as running water is not always available. Such alcoholbased hand rubs can be constituted in local pharmacies and made available on a regular basis for hospital use.

\section{Conclusion}

This study established that the participants have good knowledge of hand hygiene but compliance ratneeds to be improved upon. The main identified limitations are non availability of hand washing kits; soap, running tap water, alcohol rub, and towel or hand dryers.

We recommend the provision of these basic needs as well educational sessions to further drive the importance of hand washing to the care givers and patients which will go a long way in improving their attitude towards hand hygiene. This we believe would curb preventable infections, reducing hospital stay and cost.

Therefore, information, education, and communication should be intensified among HCW in clinical settings to reduce HAI.

\section{References}

1. Timothy $\operatorname{AE}$ (2013) Hand hygiene knowledge and practices among health care providers in a tertiary hospital, South West, Nigeria. Int J Infect Control 9: 9-14 Link: https://bit.ly/2BDgTgY

2. Boyce JM, Pittet D (2002) Guideline for Hand Hygiene in Health-Care Settings Recommendations of the Healthcare Infection Control Practices Advisory Committee and the HICPAC/SHEA/APIC/IDSA Hand Hygiene Task Force. Society for Healthcare Epidemiology of America/Association for Professionals in Infection Control/Infectious Diseases Society of America. MMWR Recomm Rep 51: 1-45. Link: https://bit.ly/3071gl9

3. Pittet D, Allegranzi B, Sax H, Dharan S, Pessoa-Silva CL, et al. (2006) Evidencebased model for hand transmission during patient care and the role of improved practices. Lancet Infect Dis 6: 641-652. Link: https://bit.ly/3g6 HqCm

4. Andersson AE, Bergh I, Karlsson J, Nilsson K (2010) Patients' experiences of acquiring a deep surgical site infection: an interview study. Am $\mathrm{J}$ Infect Control 38: 711-717. Link: https://bit.ly/32TOoH3

5. Shobowale E, Adegunle B, Onyedibe K (2016) An assessment of hand hygiene practices of healthcare workers of a semi-urban teaching hospital using the five moments of hand hygiene. Niger Med J 57: 150-154. Link: https://bit.ly/32WJ85n

6. Katz JD (2004) Hand washing and hand disinfection. more than your mother taught you. Anaesthesiol Clin North Am 22: 451-457. Link: https://bit.ly/20VM8qz

7. OB Braimoh, Udeabor SE (2013) Hand Hygiene practices among community Health officers I River state, Nigeria. Afr Health Sci 13: 507-511. Link: https://bit.ly/3jKuMv1

8. Umar MA, kehinde JA, Habibulahi A, Shamsudeen SMM (2017) Knowledge,Atittude and practice of Hand Hygiene among health care providers in semi urban communities of sokoto state, Nigeria. Int J Trop Dis Heal 2: 1-9. Link: https://bit.ly/3g5kMdh

9. Aigbiremolen AO, Abejegah C, Ike CG, Momoh JA, Lawal luKa RK ASO (2015) Knowledge and practices of Hand washing among care givers of under five children in a rural Nigerian community. Sci Acad Publ 5: 159-165. Link: https://bit.ly/2D6KaRq

10. Ekwere TA, Okafor IP (2011) Hand Hygiene Knowledge and practices among Health care providers in a tertiary Hopital,South-west Nigeria. Int $\mathrm{J}$ Infect Control 9: 1-10. Link: https://bit.ly/2BDgTgY

11. Amissah I, SaliaS CJ (2006) A study to assess hand hygiene knowledge and practice among health workers in a teaching hospital in Ghana. Int J Sci Res 5: $301-307$

12. Yildirim I, Ceyhan M, Cengiz AB, Bagdat A, Barin C, et al. (2008) A prospective comparative study of the relationship between different types of ring and microbial hand colonization among pediatric intensive care unit nurses. Int $J$ Nurs Stud 45: 1572-1576. Link: https://bit.ly/300IXFi

13. Alex-Hart BA, Opara PI (2011) Handwashing practices amongst Health Wokers in a Teaching Hospital. Am J Infect Dis 7: 8-15. Link: https://bit.ly/39D016A

14. Hosseinialhashemi M, Sadeghipour Kermani F, Palenik CJ, Pourasghari $\mathrm{H}$, Askarian M (2015) Knowledge, attitudes, and practices of health care personnel concerning hand hygiene in Shiraz University of Medical Sciences hospitals, 2013-2014. Am J Infect Control 43: 1009-1011. Link: https://bit.ly/3jlmLql

15. Asadollahi M, Arshadi Bostanabad M, Jebraili M, Mahallei M, Seyyed Rasooli A et al. (2015) Nurses' knowledge regarding hand hygiene and its individual and organizational predictors. J Caring Sci 4: 45-53. Link: https://bit.ly/334jz2a

16. Ciofi degli Atti ML, Tozzi AE, Ciliento G, Pomponi M, Rinaldi S, et al. (2011) Healthcare workers' and parents' perceptions of measures for improving adherence to hand-hygiene. BMC Public Health 11: 466. Available from: Link: https://bit.ly/2Db3sVG

17. Sarani H, Balouchi A, Masinaeinezhad N, Ebrahimitabas E (2014) Knowledge Attitude and Practice of Nurses about Standard Precautions for HospitalAcquired Infection in Teaching Hospitals Affiliated to Zabol University of Medical Sciences. Glob J Health Sci 8: 193-198. Link: https://bit.ly/2En1LVY

18. Kampf G, Kramer A (2004) Epidemiologic background of hand hygiene and evaluation of the most important agents for scrubs and rubs. Clin Microbiol Rev 17: 863-893. Link: https://bit.ly/32SFLfQ

19. Polin RA, Denson S, Brady MT (2012) Strategies for prevention of health care-associated infections in the NICU. Pediatrics 129: e1085-e1093. Link: https://bit.ly/30QQ4hS

20. Huis A, van Achterberg $T$, de Bruin M, Grol R, Schoonhoven L, et al. (2012) A systematic review of hand hygiene improvement strategies: a behavioural approach. Implement Sci [Internet] 7: 92. Link: https://bit.ly/39uEmgl

21. Omuemu V, Ogboghodo E, Opene R, Oriarewo P, Onibere O (2013) Hand hygiene practices among doctors in a tertiary health facility in southern Nigeria. J Med Trop 15: 96-101. Link: https://bit.ly/3jPEMTR

22. Erasmus V, Daha TJ, Brug H, Richardus JH, Behrendt MD, et al. (2010) Systematic review of studies on compliance with hand hygiene guidelines in hospital care. Infect Control Hosp Epidemiol 31: 283-294. Link: https://bit.ly/3031U9u

23. Bloomfield SF, Aiello AE, Cookson B, O'Boyle C, Larson EL (2007) The effectiveness of hand hygiene procedures in reducing the risks of infections in home and community settings including handwashing and alcohol-based hand sanitizers. Am J Infect Control 35: S27-S64. Link: https://bit.ly/39y1CKA

24. Shinde MB MVR (2014) A study to assess knowledge, attitude and practices of five moment of hand hygiene among Nursing staff and students at tertiary care hospital at karad. Int J Sci Res 3: 311-321. Link: https://bit.ly/3jLg9r2

Citation: Agbana RD, Ogundeji SP, Owoseni JS (2020) A survey of hand hygiene knowledge, attitude and practices among health care workers in a tertiary hospital Southwestern Nigeria. Arch Community Med Public Health 6(2): 146-151. DOI: https://dx.doi.org/10.17352/2455-5479.000095 
25. Abd Elaziz KM, Bakr IM (2009) Assessment of knowledge, attitude and practice of hand washing among health care workers in Ain Shams University hospitals in Cairo. J Prev Med Hyg 50: 19-25. Link: https://bit.ly/3eYyBJb

26. Morrison LG, Yardley L (2009) What infection control measures will people carry out to reduce transmission of pandemic influenza? A focus group study. BMC Public Health 9: 258. Link: https://bit.ly/30SxyFB

27. Moody J, Septimus E, Hickok J, Huang SS, Platt R, et al. (2013) Infection prevention practices in adult intensive care units in a large community hospital system after implementing strategies to reduce health care-associated, methicillin-resistant Staphylococcus aureus infections. Am J Infect Control 41: 126-130. Link: https://bit.ly/30Ilk16

28. Abdulraheem I, Amodu M, Saka MJ, Bolarinwa OA, Uthman MMB (2013) Knowledge, awareness and compliance with standard precautions among Health workers in North Eastern Nigeria. J Community Med Heal Edu 2: 131 136. Link: https://bit.ly/3jHVd4e
29. Megeus V, Nilsson K, Karlsson J, Eriksson BI, Andersson AE (2015) Hand hygiene and aseptic techniques during routine anesthetic care - observations in the operating room. Antimicrob Resist Infect Control 4: 5. Link: https://bit.ly/3022291

30. Pittet D, Allegranzi B, Storr J, Bagheri Nejad S, Dziekan G, et al. (2008) Infection control as major world health Organization priority for for developing countries. J Hosp Infect 68: 286-292. Link: https://bit.ly/3f6ELHg

31. Sarma JB, Ahmed GU (2010) Infection control with limited resources: why and how to make it possible? Indian J Med Microbiol 28: 11-16. Link: https://bit.ly/3hF4poc

32. World Health Organization (2009) WHO Guidelines on hand hygiene in Health Care. Geneva: World Health Organization. Link: https://bit.ly/3009BNv

\section{Discover a bigger Impact and Visibility of your article publication with} Peertechz Publications

\section{Highlights}

* Signatory publisher of ORCID

* Signatory Publisher of DORA (San Francisco Declaration on Research Assessment)

* Articles archived in worlds' renowned service providers such as Portico, CNKI, AGRIS, TDNet, Base (Bielefeld University Library), CrossRef, Scilit, J-Gate etc.

* Journals indexed in ICMJE, SHERPA/ROMEO, Google Scholar etc.

* OAI-PMH (Open Archives Initiative Protocol for Metadata Harvesting)

* Dedicated Editorial Board for every journal

* Accurate and rapid peer-review process

* Increased citations of published articles through promotions

* Reduced timeline for article publication

Submit your articles and experience a new surge in publication services

(https://www.peertechz.com/submission).

Peertechz journals wishes everlasting success in your every endeavours.

Copyright: (c) 2020 Agbana RD, et al. This is an open-access article distributed under the terms of the Creative Commons Attribution License, which permits unrestricted use, distribution, and reproduction in any medium, provided the original author and source are credited.

Citation: Agbana RD, Ogundeji SP, Owoseni JS (2020) A survey of hand hygiene knowledge, attitude and practices among health care workers in a tertiary hospital, Southwestern Nigeria. Arch Community Med Public Health 6(2): 146-151. DOI: https://dx.doi.org/10.17352/2455-5479.000095 